\title{
In vitro attenuation of classic metastatic melanoma-related features by highly diluted natural complexes: Molecular and functional analyses
}

\author{
JENIFER PENDIUK GONÇALVES $^{1 *}$, FRANCINE BITTENCOURT POTRICH ${ }^{1 *}$, \\ MARIA LUIZA FERREIRA DOS SANTOS ${ }^{1}$, VIVIANA STEPHANIE COSTA GAGOSIAN ${ }^{1}$, \\ GUSTAVO RODRIGUES ROSSI ${ }^{1}$, THIAGO JACOMASSO ${ }^{1}$, ALINE MENDES ${ }^{2}$, \\ HELENA BONCIANI NADER ${ }^{2}$, SHEILA MARIA BROCHADO WINNISCHOFER ${ }^{3}$, \\ EDVALDO S. TRINDADE ${ }^{1}$ and CAROLINA CAMARGO DE OLIVEIRA ${ }^{1}$
}

\author{
${ }^{1}$ Laboratory of Inflammatory and Neoplastic Cells/Laboratory of Sulfated Polysaccharides Investigation, \\ Cell Biology Department, Section of Biological Sciences, Federal University of Paraná, CEP 81530-980 Curitiba-PR; \\ ${ }^{2}$ Biochemistry Department, Federal University of São Paulo, São Paulo - SP 04023-062; \\ ${ }^{3}$ Biochemistry and Molecular Biology Department, Section of Biological Sciences, \\ Federal University of Paraná, CEP 81530-980 Curitiba-PR, Brazil
}

Received December 9, 2018; Accepted April 12, 2019

DOI: 10.3892/ijo.2019.4846

\begin{abstract}
Metastasis is responsible for the majority of deaths among patients with malignant melanoma. Despite recent advances, the majority of current and modern therapies are ineffective and/or financially unfeasible. Thus, in this study, we investigated two low-cost highly-diluted natural complexes (HDNCs) that have been shown to be effective against malignant melanoma in a murine model in vivo. The aim of this study was to determine the mechanisms through which these HDNCs directly affect melanoma cells, either alone or in an artificial tumor microenvironment, suppressing the metastatic phenotype, thus explaining previous in vivo effects. For this purpose, HDNC in vitro treatments of B16-F10 melanoma cells, alone or in co-culture with Balb/3T3 fibroblasts, were carried out. Molecular biology techniques and standard functional assays were used to assess the changes in molecule expression and in cell behaviors related to the metastatic phenotype. Melanoma progression features were found to be regulated by HDNCs. Molecules related to cell adhesion (N-cadherin, $\beta 1$-integrin and $\mathrm{CD} 44$ ), and
\end{abstract}

Correspondence to: Dr Carolina Camargo de Oliveira, Laboratory of Inflammatory and Neoplastic Cells/Laboratory of Sulfated Polysaccharides Investigation, Cell Biology Department, Section of Biological Sciences, Federal University of Paraná, Av Cel Francisco H dos Santos, s/n, CEP 81530-980, Curitiba-PR, Brazil

E-mail: krokoli@ufpr.br

*Contributed equally

Key words: B16-F10, high dilution, adhesion molecules, invasion, tumorigenesis, tumor microenvironment migration, extracellular matrix remodeling and angiogenesis were modulated. The cell migratory, invasive and clonogenic capacities were reduced by the HDNCs. No loss of cell proliferation or viability were observed. On the whole, the findings of this study indicate that HDNCs directly reprogram, molecularly and functionally, melanoma cells in vitro, modulating their metastatic phenotype. Such findings are likely to be responsible for the attenuation of tumor growth and lung colonization previously observed in vivo.

\section{Introduction}

Global cancer statistics are discouraging to patients: Cancers are among the top lethal diseases (1). Skin cancers are most commonly found in individuals with fair skin (2); in the USA, approximately 9,000 patients die from melanoma each year (3); the long-term survival rates for patients with advanced metastatic melanoma range from 10 to $15 \%$ (4). Although the early diagnosis and surgical removal of melanoma are efficient in approximately $80 \%$ of cases (5), melanoma cells are very likely to spread to other organs and establish metastasis, which is responsible for the highest rates of mortality among patients with skin cancer (6).

Considering the high metastatic capacity of melanomas, some anti-metastatic drugs have been tested. For example, selumetinib (7) or the combination of celecoxib and dacarbazine (8) have been shown to be effective in reducing melanoma metastasis to the liver and lungs, respectively, in mouse models. However, the majority of clinically-available conventional chemotherapeutic drugs are currently of limited value for the treatment of metastatic melanoma (9). Over the past years, the treatment of melanoma has undergone revolutionary breakthroughs alongside the evolution of targeted therapies $(10,11)$. However, despite the increased 
response achieved by the combination of chemotherapeutic agents (e.g., dacarbazine and temozolomide), or those added to cytokines [such as interferon and interleukin (IL)-2], up until the last decade, no significant impact on the survival of patients with metastatic melanoma had been achieved (12).

Cancer cells are well known to possess high proliferation rates, sustaining growth signaling and evading cell growth control, in addition to circumventing cell death (13). This is the reason why the majority of chemotherapeutic agents currently used are directly or indirectly cytotoxic to cancer cells. Although apparently contradictory, cytotoxicity is in fact not desirable, since normal tissues also present a proliferation of the cell population for maintaining tissue homeostasis. Therefore, cytotoxic drugs are often not selective to the tumor. On the other hand, modern targeted therapies have been changing the way of treating melanoma. However, they are extremely dependent on the tumor genetic signature, which is highly variable among patients (14). Additionally, the astronomic cost of modern cancer treatments has been recently brought to the attention of the scientific community, costs that place such treatments out of reach for the majority of individuals, even with public health funds (15). In the USA, a 3.5-fold increase in the annual treatment of patients with melanoma by 2030 has been foreseen (3). Such forecasts call for advancements in treatment strategies; however, state-of-the-art treatments are produced on a small scale, rendering them inaccessible to the majority of patients (11).

In light of the aforementioned challenges, new strategies for the treatment of diseases are being developed worldwide, such as those based on traditional and complementary medicine, including high dilutions as homeopathy. Individuals choosing such treatments are often motivated by increased benefits and lower costs (16). The scientific understanding on the field has grown considerably. A number of recent studies have described the antitumor activity of highly diluted medicines for different cancer types in vitro (17-22). In addition, the integration of high dilutions into public health care systems is increasing. In 2006, Brazil recognized homeopathy as part of the National Policy of Integrative and Complementary Practices and since then, the demand for this type of therapy has been increasing annually in the country (23).

Finding cost-effective treatments for selected diseases has been a priority in our research group. Over the past years, we have investigated, in vitro (24-31) and in vivo (32-36), the effects of highly diluted natural complexes (HDNCs). Lately, we have focused on two specific HDNCs, namely M1 and M8. Anti-melanoma effects have been described for both HDNCs in melanoma-bearing mice. Lung colonization was shown to be attenuated in mice injected with B16-F10 melanoma cells, followed by M8 (36) or M1 (35) treatments. Decreased proliferation, combined with the induction of cell death were found in the tumor microenvironment of these M1-treated mice. In addition, tumor growth was impaired in solid B16-F10-derived subcutaneous tumors by a decrease in cell proliferation and angiogenesis, as well as by an enhancement of cell death (35). From these studies, we have been trying to elucidate the cellular mechanisms behind such effects.

Metastasis is a multi-step process driven by selective interactions that occur during circulation (37). Altered profiles of adhesion molecules, leading to changes in migration patterns (38), coupled with the high production of proteolytic enzymes, favors the degradation of the extracellular matrix (ECM)-conferred barrier, rendering the invasion of adjacent tissues possible (39). Finally, metastatic colonization and solid tumor growth rely on individual cell competence to generate a colony.

In spite of phenotypic modified characteristics, malignant cancer cells do not act alone on disease development. Tumors are complex structures composed of multiple cell types that participate in heterotypic interactions, forming tumor microenvironments (40). Intercellular communication is driven by complex and dynamic networks of adhesion molecules, cytokines, chemokines, growth factors, inflammatory enzymes and ECM remodeling (41). In this context, fibroblasts are stimulated by tumor cells to differentiate into cancer-associated fibroblasts (CAFs), being able to influence virtually all processes that lead to melanoma progression $(40,42)$. Not only direct cell contact, but also extracellular release molecules, as well as paracrine factors are important for tumor progression (43).

For a number of years, scientists and physicians have considered that the anti-tumor effects of high dilutions were due solely to immune system activation. However, we have found that treatment with M1 in vivo did not affect immune cell numbers in metastatic melanoma-bearing mouse lungs (35). Additionally, the effects of M1 seem to occur irrespective of lymphocyte-mediated immunity (unpublished data). Therefore, our current hypothesis is that M1 and M8 may act directly on cancer cells, without cytotoxicity, suppressing the metastatic phenotype. Bearing in mind the relatively low cost and high effectiveness of both HDNCs, the aim of this study was to elucidate the mechanisms that led to previous in vivo observations. For this purpose, we used standard in vitro assays to determine the mechanisms through which M1 or M8 directly affect melanoma cell malignancy parameters, alone or in an artificial tumor microenvironment (co-cultured with fibroblasts), acting as molecular and functional modulators for melanoma cells.

\section{Materials and methods}

HDNCs, cell culture and in vitro treatment. HDNCs were produced as recommended by the Brazilian Homeopathic Pharmacopoeia. The components followed by their dilution and final concentration in M8 were as follows: Aconitum napellus $\left(20 \mathrm{dH}, 0.1 \times 10^{-19}\right)$, Arsenicum album $(18 \mathrm{dH}$, $\left.0.1 \times 10^{-17}\right)$, Asafoetida $\left(20 \mathrm{dH}, 0.1 \times 10^{-19}\right)$, Calcarea carbonica $\left(16 \mathrm{dH}, 0.1 \times 10^{-15}\right)$, Conium maculatum $\left(17 \mathrm{dH}, 0.1 \times 10^{-16}\right)$, Ipecacuanha $\left(13 \mathrm{dH}, 0.1 \times 10^{-12}\right)$, phosphorus $\left(20 \mathrm{dH}, 0.1 \times 10^{-19}\right)$, Rhus toxicodendron $\left(17 \mathrm{dH}, 0.1 \times 10^{-16}\right)$, Silicea $(20 \mathrm{dH}$, $\left.0.1 \times 10^{-19}\right)$, sulphur $\left(24 \mathrm{dH}, 0.1 \times 10^{-23}\right)$ and Thuja occidentalis $\left(19 \mathrm{dH}, 0.1 \times 1^{0-18}\right)$. M1 has the same basic composition as M8, with the addition of Chelidonium majus $\left(20 \mathrm{dH}, 0.1 \times 10^{-19}\right)$, cinnamon $\left(20 \mathrm{dH}, 0.1 \times 10^{-19}\right)$, Echinacea purpurea $(20 \mathrm{dH}$, $\left.0.1 \times 10^{-19}\right)$ and Gelsemium sempervirens $\left(20 \mathrm{dH}, 0.1 \times 10^{-19}\right)$, as previously described (29). They were prepared trough serial decimal dilutions from mother tinctures, which were obtained at Schraibmann Laboratory Ltd. (Carapicuíba, Brazil). M1, as well as M8 preparations were achieved by mixing and diluting those mother tinctures and pre-diluted solutions to the desired final concentration of each component in the HDNC. In the 
end, M1 and M8 were used separately and were not mixed together. Between each dilution steps, the solutions were vigorously shaken 100 times against a soft pad. Final products are colorless and odorless and contain $0.1 \%$ ethanol. Traces of ethanol present in highly diluted medicines may exert direct effects on cell behavior in vitro $(44,45)$. For this reason, the last $3 \mathrm{M} 1$ and M8 dilutions were performed in distilled water, and water was used as a control. HDNCs and vehicle control (water) were $0.22-\mu \mathrm{m}$ filtered, sterilized and stored at room temperature, protected from light until use.

Murine B16-F10 melanoma (BCRJ, 0046) and Balb/3T3 fibroblasts (ATCC, CCL-163) were maintained in complete medium, Dulbecco's modified Eagle's medium (DMEM), $10 \%$ fetal bovine serum (FBS), $1 \mathrm{U} / \mathrm{ml}$ penicillin, $1 \mu \mathrm{g} / \mathrm{ml}$ streptomycin (all from Gibco/Thermo Fisher Scientific, Waltham, $\mathrm{MA}, \mathrm{USA}$ ), at $37^{\circ} \mathrm{C}$ and $5 \% \mathrm{CO}_{2}$, for no more than 5 passages. For subculturing, the cells were washed with PBS and incubated with trypsin for $3 \mathrm{~min}$ at $37^{\circ} \mathrm{C}$, followed by complete medium inactivation. For co-culture assays, the cells were simultaneously plated at a 1:1 ratio. Following treatment, the mRNA of both cells and their supernatant was collected for analysis. Both cell lineages were shown to be mycoplasma-free after staining with DAPI and imaging under a confocal laser scanning microscope [Nikon A1RMP (Tokyo, Japan) + 100X objective] (46).

At $6 \mathrm{~h}$ after cell seeding, M1, M8, or distilled water were added to each respective group as $20 \%$ (v/v) of cell culture media final volume on the well. Both M1 and M8 were used as prepared, with no further dilutions. A $1 \%$ (v/v) booster dose was provided every $24 \mathrm{~h}$. For proliferation and viability assays, the cells were treated for up to $96 \mathrm{~h}$. For other functional and molecular assays, the cells were pre-treated for $96 \mathrm{~h}$. The solutions were vigorously shaken 20 times against an open hand palm, immediately prior to treatment.

Migration and invasion assays. Melanoma cell migration and invasion were determined according to previously described protocols (47). For scratch assay, confluent treated cells were scratched using $10 \mu \mathrm{l}$ tip, and imaged under an inverted AxioObserver Z1 microscope (Carl Zeiss, Jena, Germany), over a heating plate at $37^{\circ} \mathrm{C}$ for up to $24 \mathrm{~h}$ to follow scratch closure. The distance between the scratched edges was measured using Image J $1.52 \mathrm{n}$ software.

Transwell migration was determined using $8 \mu \mathrm{m}$ PVP-free carbonate Transwell plates (Millipore, Tullagreen, Ireland). Chemoattractants were added to lower filters surface $(0.1 \mu \mathrm{g} / \mu 1$ fibronectin $)$ and lower chamber (DMEM + 20\% FBS). Pre-treated cells were mechanically detached, suspended in DMEM and added to the upper Transwell chamber $\left(2 \times 10^{5}\right.$ cells/chamber $)$. The plates were incubated for $28 \mathrm{~h}$ under culture conditions at $37^{\circ} \mathrm{C}$. The cells were fixed in $2 \%$ paraformaldehyde and then stained with $0.25 \mathrm{mg} / \mathrm{ml}$ crystal violet $(\mathrm{CV})$ (both from EMS, Hatfield, PA, USA) for $10 \mathrm{~min}$. The upper surface cells were then removed, and the migrating cells were imaged under an optic microscope Eclipse E200 (Nikon). CV was eluted in $33 \%$ acetic acid, followed by absorbance reading at $570 \mathrm{~nm}$ using an Epoch ${ }^{\mathrm{TM}}$ Microplate Spectrophotometer (BioTek Instruments, Winooski, VT, USA).

BioCoat Matrigel Invasion Chambers $8 \mu \mathrm{m}$ PET-membrane (Corning Inc., Corning, NY, USA) were used for the invasion assay. The complete medium was added to the lower chamber as a chemoattractant. Pre-treated cells were mechanically detached, suspended in DMEM, added to the upper chamber $\left(8 \times 10^{4}\right.$ cells/chamber), and incubated for $72 \mathrm{~h}$ under culture conditions at $37^{\circ} \mathrm{C}$. The cells were fixed with $2 \%$ paraformaldehyde(EMS), the upper surface cells were wiped off, and the invaded cells were stained/mounted in Dapi-Fluoromount-G ${ }^{\mathrm{TM}}$ (EMS) and imaged using an Axio Imager Z2 microscope (Carl Zeiss).

Reactive oxygen species (ROS) detection. The $\mathrm{H}_{2} \mathrm{DCFDA}$ probe (Sigma-Aldrich, St. Louis, MO, USA) was used to determine the intracellular ROS levels (48). Pre-treated cells were incubated with $2.5 \mu \mathrm{M} \mathrm{H}_{2} \mathrm{DCFDA}$ in PBS for $30 \mathrm{~min}$ at $37^{\circ} \mathrm{C}$, and the fluorescence intensity detected using a FACSCalibur (BD Biosciences, Franklin Lakes, NJ, USA) flow cytometer. $\mathrm{H}_{2} \mathrm{O}_{2}$ was used as an internal positive control.

Hyaluronic acid detection. Hyaluronic acid (HA) was quantified using HA-binding probes (49). Culture supernatants were incubated overnight at $56^{\circ} \mathrm{C}$ with $6 \mathrm{mg} / \mathrm{ml}$ maxatase, then boiled and incubated overnight at $4^{\circ} \mathrm{C}$ in ELISA plates pre-adsorbed with probes. Biotinilated probes and europium-conjugated streptavidin were used to detect HA. DELFIA Enhancement Solution (PerkinElmer, Waltham, MA, USA) was added and fluorescence detected using Victor-2 fluorimeter (PerkinElmer-Wallac ${ }^{\circledR}$; PerkinElmer). Data were normalized by the cellular protein concentration following the manufacturer's instructions for the BCA Protein Assay kit (Thermo Fisher Scientific).

Cells immunolabeling. The cells were fixed in $2 \%$ paraformaldehyde (EMS), blocked with $0.1 \mathrm{M}$ glycine (VETEC/Sigma-Aldrich, Rio de Janeiro, Brazil) and permeabilized with $0.01 \%$ saponin (Sigma-Aldrich). The cells were incubated with primary antibodies in $1 \%$ BSA (Sigma-Aldrich) for $1 \mathrm{~h}$ and with appropriate secondary antibody for $45 \mathrm{~min}$, both at room temperature. Information regarding the source and target species, as well as the dilutions used is presented in Table I. The cell fluorescence intensity and/or positive cell percentage were obtained using a FACSCalibur (BD Biosciences) flow cytometer.

$R T$ - $q P C R$. Total RNA was extracted using the E.Z.N.A. RNA Extraction kit (Omega Bio-tek, Norcross, GA, USA) cDNA was reverse transcribed from $500 \mathrm{ng}$ total RNA using the High Capacity cDNA Reverse Transcription kit (Applied Biosystems/Thermo Fisher Scientific, Foster City, CA, USA) as per the manufacturer's instructions. qPCR was performed using the Power SYBR-Green kit (Applied Biosystems) using $2 \mu \mathrm{l}$ of cDNA diluted 1:10 in water. The primer concentration was $800 \mathrm{nM}$ for all targets. The primer sequences are listed in Table II. The reaction was performed on a StepOne Plus thermal cycler (Applied Biosystems/Thermo Fisher Scientific), using the following cycle conditions: $95^{\circ} \mathrm{C}$ for $10 \mathrm{~min}$, followed by 40 cycles of $95^{\circ} \mathrm{C}$ for $15 \mathrm{sec}$ and $60^{\circ} \mathrm{C}$ for $1 \mathrm{~min}$. Finally, a melting step was performed, ramping from 60 to $95^{\circ} \mathrm{C}$, to ensure that no secondary PCR product was interfering with the analysis. The $\mathrm{Cp}$ was obtained using StepOne Software version 2.3. Expression data were analyzed by geometric averaging of multiple internal control genes (GAPDH, HPRT 
Table I. List of antibodies used in flow cytometry and western blot analysis.

\begin{tabular}{|c|c|c|}
\hline Antibody & Company (cat. no.) & Dilution \\
\hline Monoclonal rat anti-mouse CD44 IgG2b & BD Biosciences, San Jose, CA, USA (550538) & $0.625 \mu \mathrm{g} / \mathrm{ml}$ \\
\hline Polyclonal goat anti-human N-cadherin IgG & Santa Cruz Biotechnology, Santa Cruz, CA, USA (sc-31030) & $40 \mu \mathrm{g} / \mathrm{ml}$ \\
\hline Monoclonal rabbit anti-human $\beta 1$-integrin IgG & Millipore, Billerica, MA, USA (04-1109) & $1: 500$ \\
\hline Polyclonal rabbit anti-mouse heparanase IgG & Santa Cruz Biotechnology, Santa Cruz, CA, USA (sc-25826) & $2 \mu \mathrm{g} / \mathrm{ml}$ \\
\hline Polyclonal goat FITC-conjugated anti-rat IgG & Jackson Laboratories, Bar Harbor, ME, USA (112-095-003) & $1: 200$ \\
\hline $\begin{array}{l}\text { Polyclonal rabbit Alexa Fluor 488-conjugated } \\
\text { anti-goat IgG }\end{array}$ & $\begin{array}{l}\text { Invitrogen/Thermo Fisher Scientific, } \\
\text { Waltham, MA, USA (A11078) }\end{array}$ & $6.7 \mu \mathrm{g} / \mathrm{ml}$ \\
\hline $\begin{array}{l}\text { Polyclonal donkey FITC-conjugated } \\
\text { anti-rabbit IgG }\end{array}$ & Jackson Laboratories, Bar Harbor, ME, USA (711-095-152) & $5 \mu \mathrm{g} / \mathrm{ml}$ \\
\hline
\end{tabular}

Table II. Primers sequences used for RT-qPCR.

\begin{tabular}{lll}
\hline Gene & \multicolumn{1}{c}{ Forward sequence } & \multicolumn{1}{c}{ Reverse sequence } \\
\hline N-cadherin & 5'-TTGCTTCAGGCGTCTGTGGAG-3' & 5'-ACATCCTTCGGTAAGACTGCG-3' \\
Hyaluronidase-1 & 5'-AAAGTTTGGAGAATGAAGCCCT-3' & 5'-GGTTGGATACCACGGAACCT-3' \\
HSPG2 & 5'-CCGTCCTGGTCTCGATTACA-3' & 5'-AGGAAGTCTCGATGCGGATG-3' \\
Sulfatase-2 & 5'-CCTTCGCCGTGTATCTCAAC-3' & 5'-CACGTATGAGCCGTTGTACTC-3' \\
PDGF-A & 5'-AGGAGGAGACAGATGTGAGGT-3' & 5'-TTCAGGAATGTCACACGCCA-3' \\
PDGF-B & 5'-GGAGTCGGCATGAATCGCT-3' & 5'-GAATGGGATCCCCCTCGG-3' \\
PDGF-C & 5'-GGAACAGAACGGAGTGCAAGA-3' & 5'-GGCTGTGGATGCTCCCATTA-3' \\
GAPDH & 5'-ATCTTCTTGTGCAGTGCCAG-3' & 5'-GGCAACAATCTCCACTTTGCC-3' \\
HPRT & 5'-TCCCTGGTTAAGCAGTACAGCCCC-3' & 5'-AGTCTGGCCTGTATCCAACACTTCG-3' \\
ACTB & 5'-AAGATCAAGATCATTGCTCCTG-3' & 5'-CGTACTCCTGCTTGCTGATC-3' \\
\hline
\end{tabular}

and $A C T B$ ) expression values, calculated using geNorm application, as previously described by Vandesompele et al. GeNorm calculates the gene-stability for all control genes in a given set of samples, allowing normalization by multiple housekeeping genes instead of one (50). After the normalization of the target gene by multiple housekeeping ones, treated samples were compared to the respective control of each individual experiment.

Gelatin zymography. Zymography was performed as previously described (51). Sample media were replaced for DMEM after $96 \mathrm{~h}$ of treatment. Supernatants were collected $24 \mathrm{~h}$ later, mixed with non-reducing sample buffer and electrophoretically separated on an $8 \%$ polyacrylamide gel containing $1 \mathrm{mg} / \mathrm{ml}$ gelatin (Fluka, Steinheim, Germany). The gels were incubated in matrix metalloproteinase (MMP) optimum incubation buffer for $72 \mathrm{~h}$ at $37^{\circ} \mathrm{C}$, stained with Coomassie Brilliant Blue R-250 (VETEC/Sigma-Aldrich) $0.5 \%(\mathrm{w} / \mathrm{v})$ in $30 \%$ methanol and $10 \%$ glacial acetic acid for $30 \mathrm{~min}$ at room temperature, and imaged in Eu-88 A3 Transparency Unit (Epson, Tokyo, Japan). Degradation bands related to MMP-2 activity were quantified using Image J $1.52 \mathrm{n}$ software. Data were normalized by the adherent cell number/well, which was obtained by CV staining.

Clonogenic assay. Pre-treated B16-F10 cells were mechanically detached, suspended in complete medium containing
$10 \%$ firming buffer, and added to the AlgiMatrix 3D Culture System (both from Gibco/Thermo Fisher Scientific) $\left(2.5 \times 10^{3}\right.$ cells/well). The plates were incubated for 6 days under culture conditions at $37^{\circ} \mathrm{C}$. The gels were fixed in $1 \%$ paraformaldehyde (EMS), stained with $0.25 \mathrm{mg} / \mathrm{ml} \mathrm{CV}$ for $20 \mathrm{~min}$ at room temperature, washed with water, transferred to checkered Petri dishes, and photographed using a smartphone, keeping always the same distance between the camera and the alginate gel for all samples. The colony number and size were quantified using ImageJ $1.52 \mathrm{n}$ software.

Proliferation, metabolic activity and cell death assays. For proliferation assessment, the cells were fixed in $2 \%$ paraformaldehyde (EMS), stained with CV for $20 \mathrm{~min}$ at room temperature, and the staining was eluted in $33 \%$ acetic acid (Merck, Darmstadt, Germany) (52). For metabolic activity determination, the cells were incubated with $5 \mathrm{mg} / \mathrm{ml}$ 3-(4,5-dimethylthiazol-2-yl)-2,5-diphenyltetrazolium bromide (MTT; Sigma-Aldrich) for $3 \mathrm{~h}$ at $37^{\circ} \mathrm{C}$. Formazan crystals were dissolved in DMSO (Sigma-Aldrich), as previously described (53). CV and MTT absorbances were read at 570 or $550 \mathrm{~nm}$, respectively, using an Epoch $^{\mathrm{TM}}$ Microplate Spectrophotometer (BioTek Instruments).

Cell death was determined using an Annexin V-FITC/ 7-AAD Apoptosis Detection kit (BD Biosciences) according to the manufacturer's instructions. The percentage of cells 
A

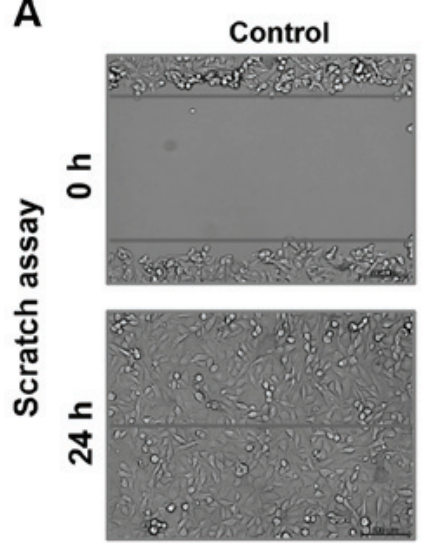

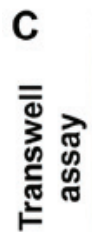
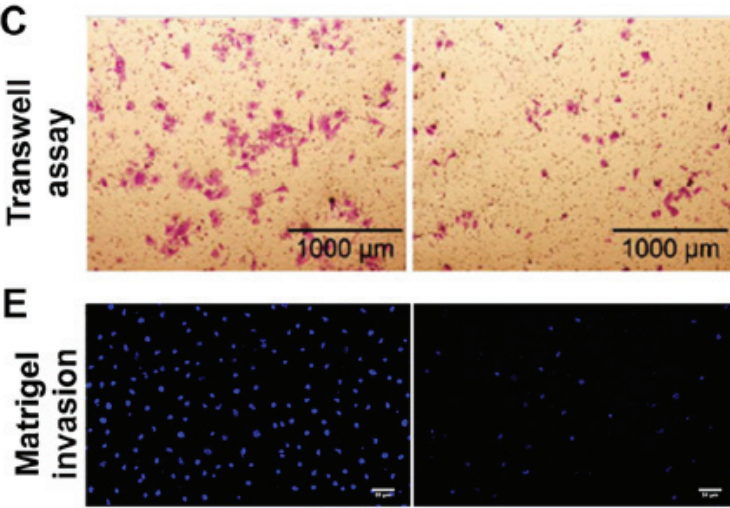
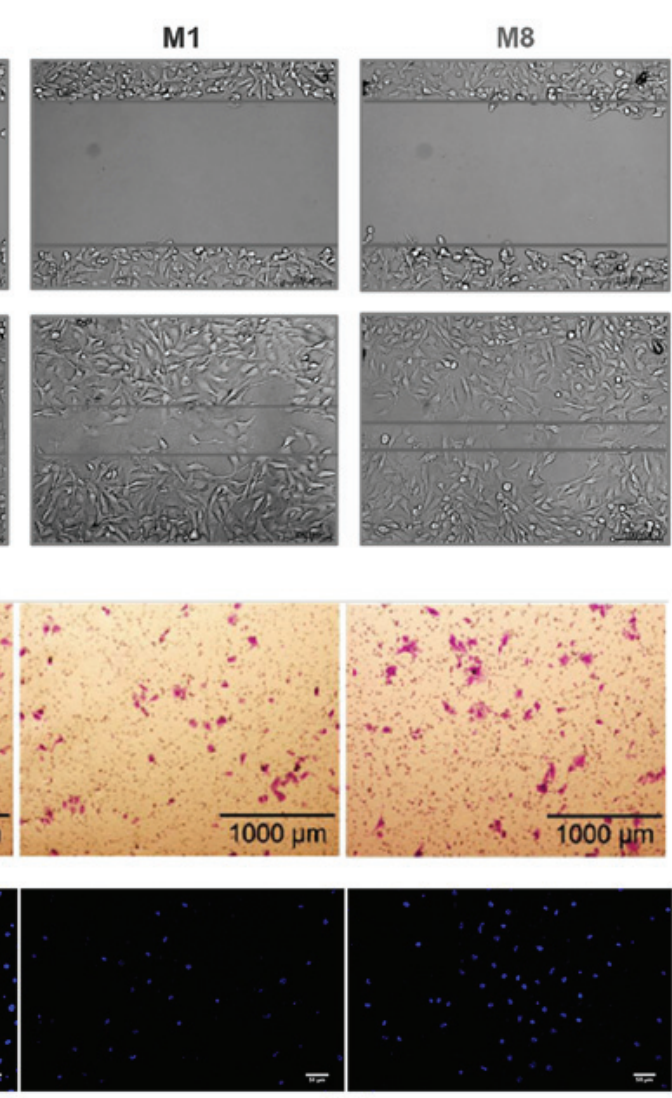

B
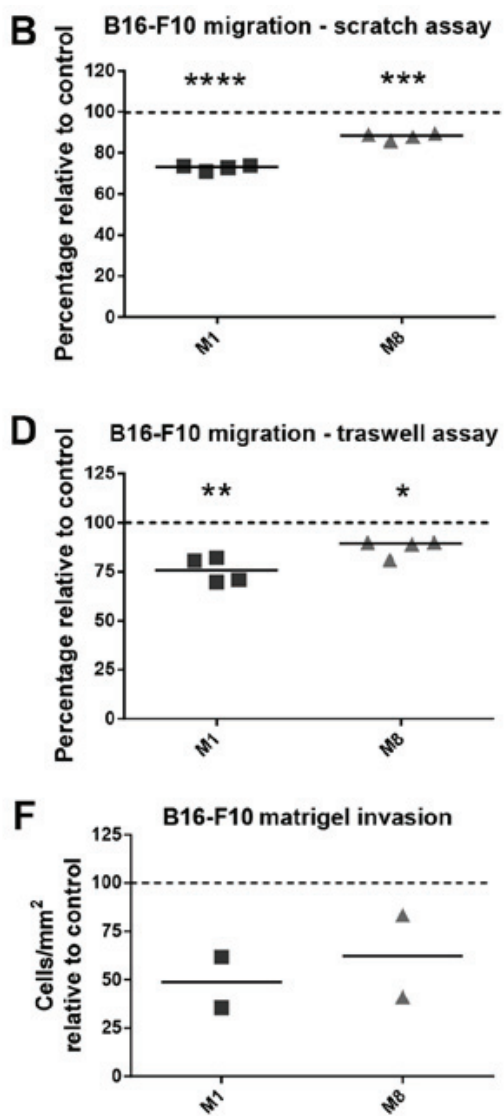

Figure 1. B16-F10 melanoma cell migratory and invasive capacity following treatment with M1 or M8. (A) Phase contrast images of initial scratches on pre-treated cells (upper panel images); $24 \mathrm{~h}$ later (bottom panel images). Scale bars, $100 \mu \mathrm{m}$. (B) y-axis shows scratch closure percentage compared to the control group. (C) Light microscopy images of Transwell bottom membrane showing migratory cells stained with crystal violet. (D) y-axis shows crystal violet absorbance compared to the absorbance of the control group. (E) Fluorescence images of Transwell bottom membrane displaying invasive cells stained with DAPI. Scale bars, $50 \mu \mathrm{m}$. (F) y-axis shows the number of invasive cells per area compared to the control group. Data from 2 (F) and 4 (B and D) independent experiments are presented. Bars represent data median. Dotted lines represent the control data normalized as 100. Data were analyzed by a paired t-test. ${ }^{*} \mathrm{P}<0.05,{ }^{* *} \mathrm{P}<0.01,{ }^{* * *} \mathrm{P}<0.001$ and ${ }^{* * * * *} \mathrm{P}<0.0001$ compared to the control.

positive for each marker was obtained using a FACSCalibur (BD Biosciences) flow cytometer.

Statistical analysis. Images and flow cytometry data were analyzed using Image J 1.52n (54) or Flowing 2 (55) software, respectively. The treated samples were compared to the vehicle control of each independent experiment using appropriate statistical tests (Paired t-test) for each experiment. For multiple comparisons, the Kruskal-Wallis test followed by Dunn's multiple comparisons test were used. P-values $<0.05$ were considered to indicate statistically significant differences.

\section{Results}

Dissemination of melanoma cells and modulation of tumor progression signature

Migratory and invasive capacities are reduced by HDNCs. First, we sought to determine whether the HDNCs can restrict the migration of melanoma cells. Scratch wound (Fig. 1A) and Transwell (Fig. 1C) assays revealed that both the HDNCs were capable of reducing the melanoma cell migratory capacity. M1 was more effective than M8 in reducing the cell migratory capacity by $27.2 \%(\mathrm{P}<0.0001)$ and $24.15 \%(\mathrm{P}=0.0049)$, as shown by scratch wound and Transwell assays, respectively, against approximately $11.93 \%(\mathrm{P}=0.0006)$ and $12.54 \%$ $(\mathrm{P}=0.0102)$ of $\mathrm{M} 8$ (Fig. 1B andD).

Next, the invasive capacity of the melanoma cells through Matrigel was evaluated. We found that the cells pre-treated with M1 and M8 exhibited a decreased ability to invade the ECM barrier (Fig. 1E and F) by 51 and 38\%, respectively.

Cell migration-related molecules are modulated by HDNCs. Flow cytometry detection revealed that M1 was able to enhance the intracellular ROS levels by $73.63 \%(\mathrm{P}=0.0209)$. No significant difference was found over M8 treatment (Fig. 2A). On the other hand, only the M8-treated cells presented an CD44 expression reduced by $13.84 \%$ ( $\mathrm{P}=0.0115$ ) (Fig. 2B).

Following treatment with the HDNCs, the percentage of melanoma cells expressing $\mathrm{N}$-cadherin and $\beta 1$-integrin was quantified by flow cytometry. Both M1 and M8 were able to downregulate the intensity of $\mathrm{N}$-cadherin surface detection by $9.09 \%(\mathrm{P}=0.0155)$ and $8.23 \%(\mathrm{P}=0.0264)$, respectively (Fig. $2 \mathrm{C})$, and the percentage of cells expressing $\beta 1$-integrin by $14.32 \%$ $(\mathrm{P}=0.0057)$ and $7.89 \%(\mathrm{P}=0.0455)$, respectively (Fig. 2D).

ECM-related molecules were differentially modulated by M1 and M8. The gelatinolytic activity of MMP-2 was examined trough gelatin zymography. Band densitometry revealed no significant changes after the melanoma cells treatment with the HDNCs (data not shown). 

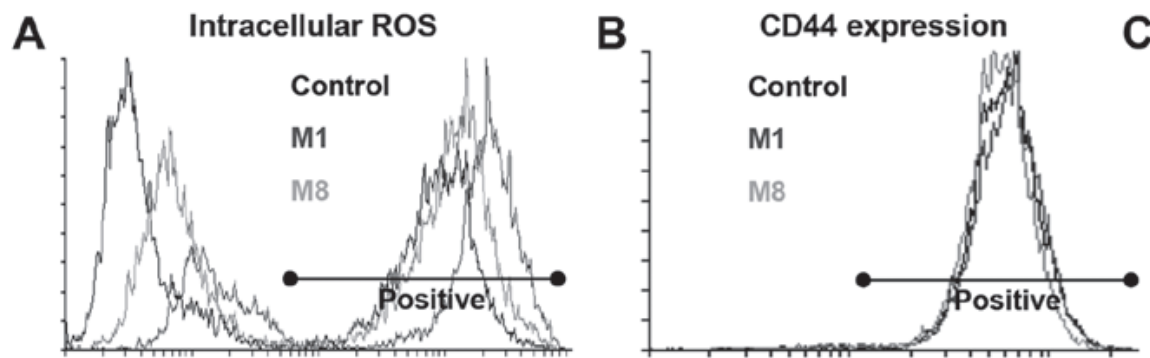

C N-cadherin expression
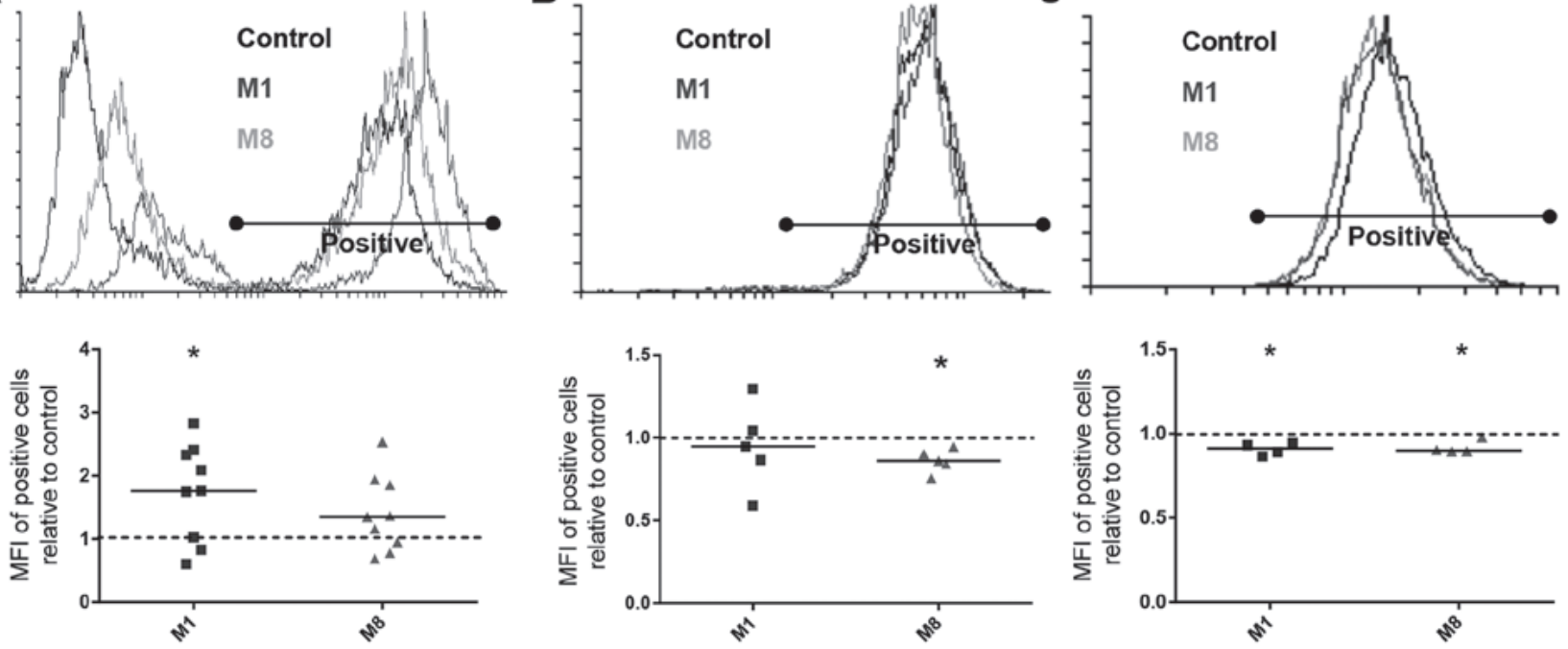

D

$\beta 1$-integrin expression

E
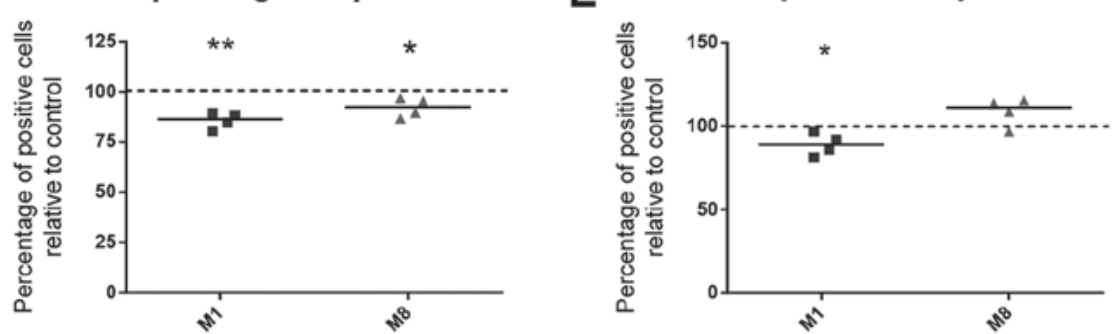

Figure 2. Expression of migration-related molecules in B16-F10 melanoma cells following treatment with M1 or M8. (A, B and C) The histograms on the upper panels are representative results of fluorescent cells labeling by flow cytometry, where the x-axis represents the fluorescence intensity. The graphs on the bottom panels show comparisons of the median fluorescence intensity (MFI) of cells ( $y$-axis) compared to the control group. (D and E) Graphs displaying positive cells percentage (y-axis) of both treated groups compared to control by flow cytometry. Data from at least 4 independent experiments are presented. Bars represent data median. Dashed lines represent control data normalized as 1 or 100 . Data were analyzed by a paired $\mathrm{t}$-test. ${ }^{*} \mathrm{P}<0.05$ and ${ }^{* *} \mathrm{P}<0.01$ compared to the control.

We also observed that neither HA secretion (data not shown) nor hyaluronidase-1 mRNA expression were altered in HDNC-treated melanoma cells (Table III). However, the melanoma cells treated with $\mathrm{M} 1$ expressed $30.1 \%(\mathrm{P}=0.0249)$ more HSPG2 mRNA (Table III), although by contrast, exhibited heparanase protein levels decreased by $11.06 \%$ $(\mathrm{P}=0.0481)$ (Fig. 2E). On the other hand, the cells treated with M8 exhibited a $36.9 \%(\mathrm{P}=0.0189)$ enhancement of sulfatase-2 mRNA expression (Table III).

MMP-2 activity is modulated in the artificial tumor microenvironment by HDNCs. Balb/3T3 fibroblasts were used as CAF model and co-cultured with B16-F10 melanoma cells. We observed that neither M1 nor M8 affected N-cadherin mRNA expression (Table IV). We also investigated HA synthesis/secretion in a co-culture context. HA synthesis was not affected by any of the HDNCs (data not shown). Using RT-qPCR, we accessed the mRNA expression of commonly produced molecules within the tumor microenvironment. M8 treatment did not induce changes in the expression of these genes. However, M1 reduced platelet-derived growth factor (PDGF)-B expression by $32.21 \%$ ( $\mathrm{P}=0.0036$ ) (Table IV).

Co-culture supernatants were used to determine MMP-2 gelatinolytic activity by gelatin zymography. We observed that both $\mathrm{M} 1$ and $\mathrm{M} 8$ were able to significantly reduce the secreted MMP-2 activity by $25.48 \%(\mathrm{P}=0.0340)$ and $30.42 \%$ ( $\mathrm{P}=0.0186$ ), respectively (Fig. 3).

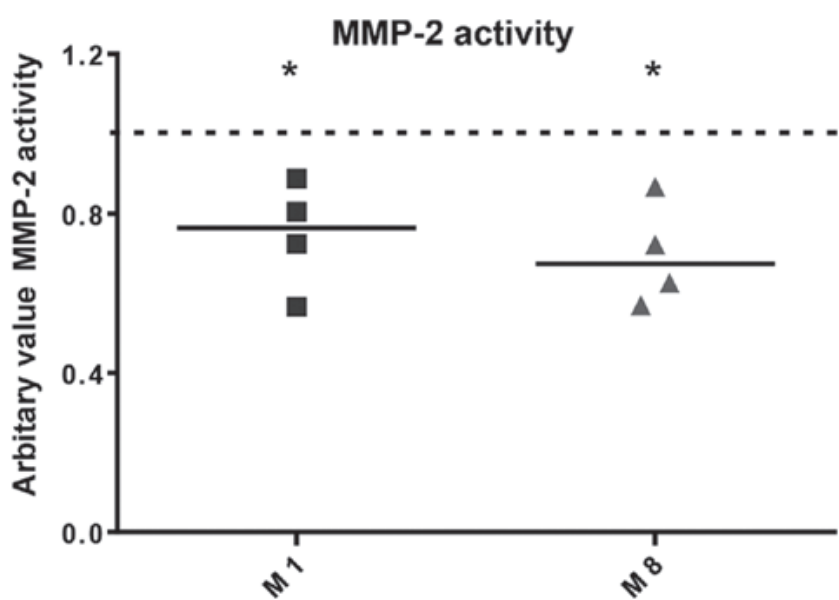

Figure 3. Matrix metalloproteinase (MMP)-2 activity of B16-F10-Balb/3T3 co-culture following treatment with M1 or M8. Graph showing band intensity densitometry normalized by cell number (y-axis) compared to control group (dashed line). Data from 4 independent experiments are presented. Bars represent data median. Data were analyzed by a paired t-test. ${ }^{*} \mathrm{P}<0.05$ compared to the control.

Clonogenic capacity of melanoma cells. Alginate gel matrix was used to determine the colony formation capacity of the melanoma cells following pre-treatment with the HDNCs (Fig. 4A). M8 reduced the number of colonies 
A

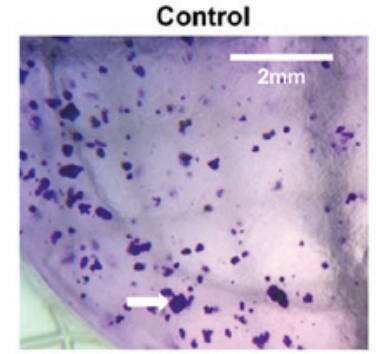

B

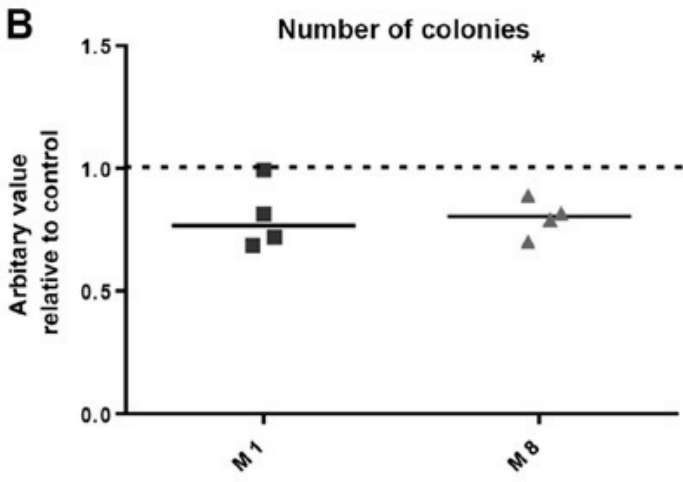

M1

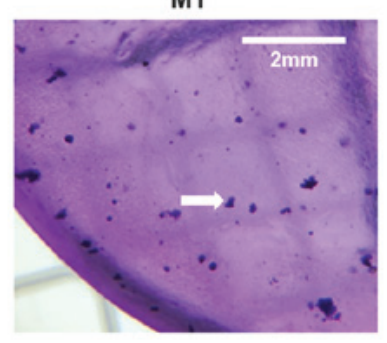

C

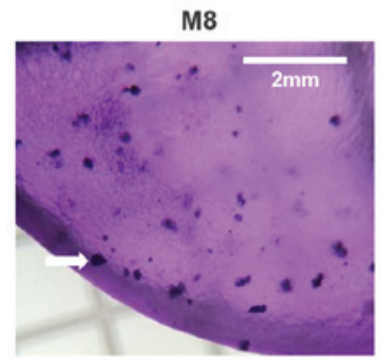

Colonies size

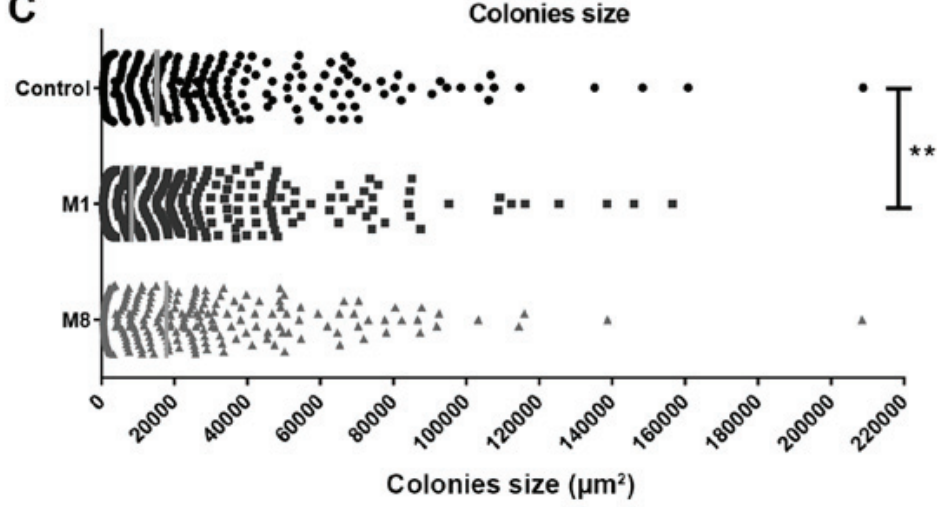

Figure 4. B16-F10 melanoma cells clonogenic capacity following treatment with M1 or M8. (A) Images showing representative fields of alginate gels containing cell colonies. Arrows indicate representative colonies in each group. Scale bars, $2 \mathrm{~mm}$. (B) Graph showing the number of colonies/area (y-axis) compared to the control group. Dashed line represents control data normalized as 1. (C) Graph displaying individual colonies size (x-axis). Bars represent data median. Data from 4 independent experiments are presented. Data were analyzed by a paired t-test (B) or Kruskal-Wallis test followed by Dunn's multiple comparisons test $(\mathrm{C})$ comparing the treated groups to the control. ${ }^{*} \mathrm{P}<0.05$ and ${ }^{* *} \mathrm{P}<0.01$ compared to the control.

Table III. Gene expression of adhesion- and extracellular matrix remodeling-related proteins in B16-F10 melanoma cells following treatment with M1 or M8.

\begin{tabular}{llc}
\hline Gene & \multicolumn{1}{c}{ M1 } & M8 \\
\hline Hyaluronidase-1 & No change & No change \\
HSPG2 & $+(30.1 \%)$ & No change \\
Sulfatase-2 & No change & $+(36.9 \%)$ \\
\hline
\end{tabular}

Data from at least 4 independent experiments are presented. M1 or M8 treatment groups were compared to each experimental control group. Data were analyzed by the paired t-test. 'No change', indicates no statistical difference compared to the control; the ' + ' symbol indicates a statistically significant increase $(\mathrm{P}<0.05)$ compared to the control.

derived from the pre-treated melanoma cells by $19.96 \%$ $(\mathrm{P}=0.0144)$, while $\mathrm{M} 1$ did not significantly affect the number of colonies (Fig. 4B). Additionally, M1 reduced the size of individual colonies by approximately $30 \%(\mathrm{P}=0.0029)$, while no significant changes were observed with M8 (Fig. 4C).

Anchorage-dependent growth and cytotoxicity. Anchoragedependent growth and cell viability were assayed in both melanoma cells and fibroblasts (non-tumor cell model). When cultured in vitro, the B16-F10 melanoma and Balb/3T3 fibroblasts are adherent cells. CV assay was used to determine the effects of the HDNCs on cell proliferation. A time-course growth curve for up to $96 \mathrm{~h}$ was performed and CV staining revealed no differences in the number of adherent cells for M1
Table IV. Gene expression of adhesion- and soluble signaling protein-related molecules in B16-F10-Balb/3T3 co-cultured following treatment with M1 or M8.

\begin{tabular}{llc}
\hline Gene & \multicolumn{1}{c}{ M1 } & \multicolumn{1}{c}{ M8 } \\
\hline N-cadherin & No change & No change \\
PDGF-A & No change & No change \\
PDGF-B & $-(32.2 \%)$ & No change \\
PDGF-C & No change & No change \\
\hline
\end{tabular}

Data from at least 4 independent experiments are presented. The M1 or M8 treatment groups were compared to each experiment control group. Data were analyzed by the paired t-test. 'No change' indicates no statistical difference compared to the control; the "-" symbol indicates a statistically significant decrease $(\mathrm{P}<0.05)$ compared to the control.

and M8 treatments, for either the melanoma cells (Fig. 5A) or the fibroblasts (Fig. 5B).

Next, regular cell features were used to determine the loss of cell viability, as well as the extent of cell damage. MTT standard assay to access cytotoxicity by measuring mitochondrial enzymes activity was used. No marked changes in metabolic activity of the melanoma cells (Fig. 5C) and fibroblasts (Fig. 5D) treated with the HDNCs were observed. In addition, to confirm that no cell damage had occurred, phosphatidylserine externalization and membrane permeabilization were determined by Annexin V and 7-AAD labeling, respectively. This assay provides a clear picture of cytotoxicity, as it can distinguish viable cells from early 
A

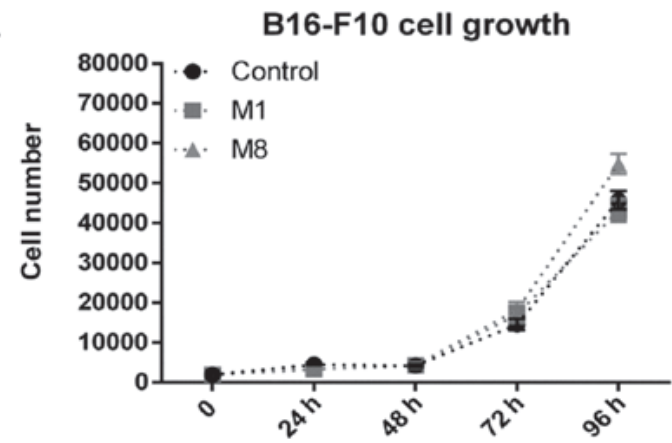

C

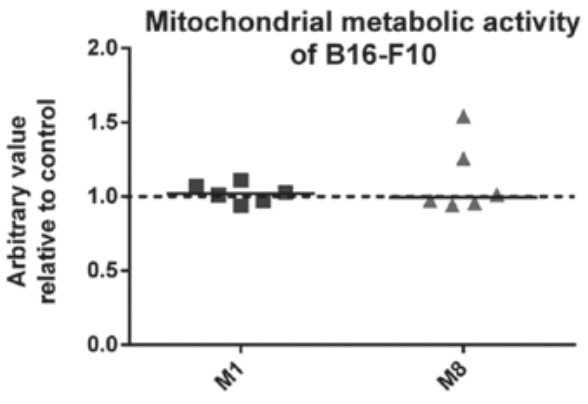

E

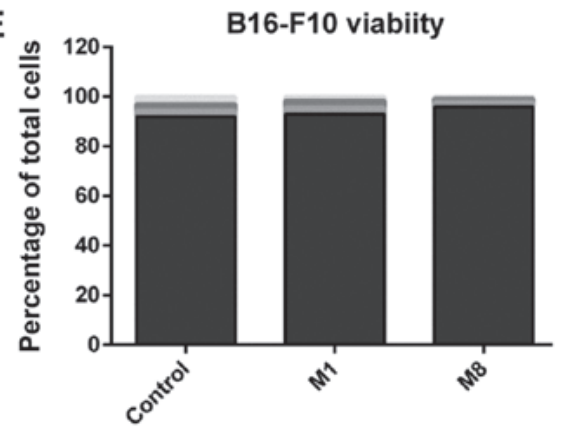

$\mathbf{F}$

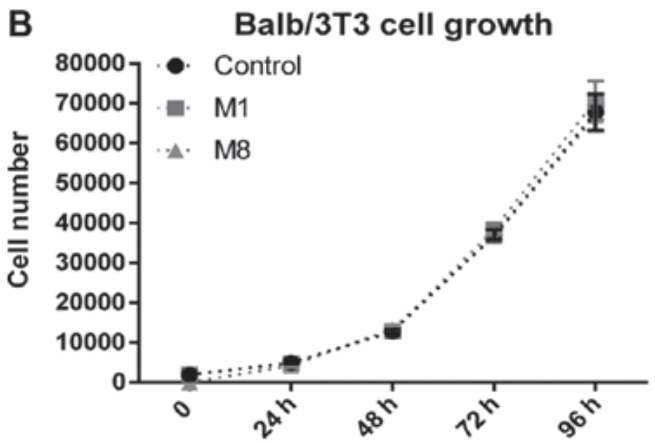

D
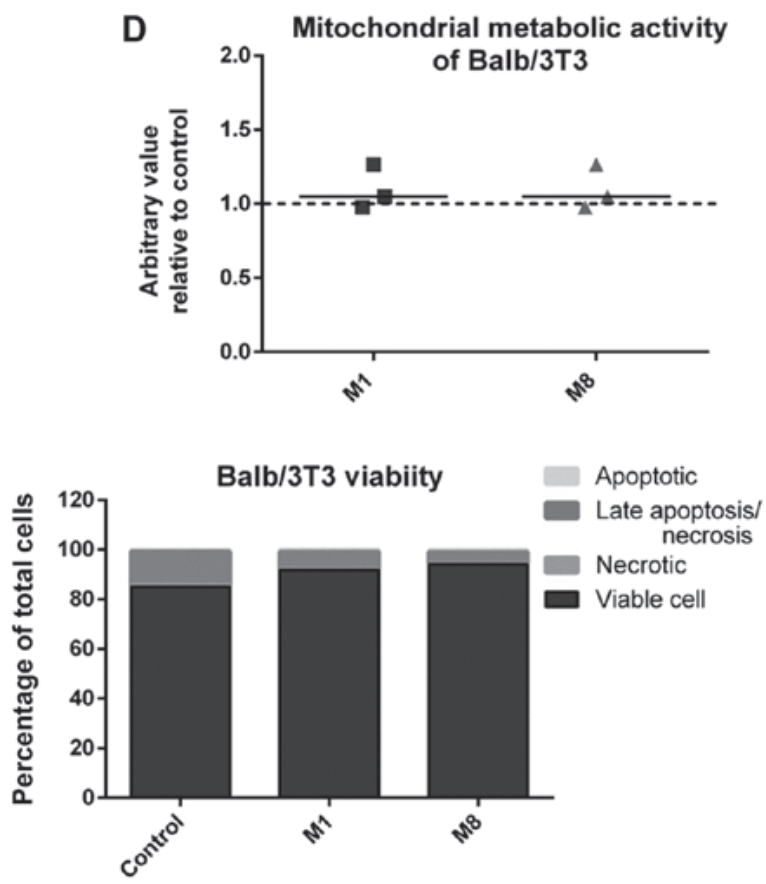

Figure 5. B16-F10 melanoma and Balb/3T3 fibroblast proliferation and viability following treatment wiht M1 or M8. (A and B) Growth curve determined by the number of adhered cells (y-axis) after each treatment period (x-axis). Data are presented as the means \pm SEM. (C and D) Normalized absorbance (y-axis) compared to control group (dashed line). Bars represent data median. (E and F) Stacked bar graphs showing Annexin V negative/7-AAD-negative, 7-AAD-positive, Annexin V-positive and Annexin V-positive/7-AAD-positive cells (y-axis). Data from at least 3 independent experiments are presented. M1 or M8 treatment groups were compared to each experimental control. (A, B, E and F) The Kruskal-Wallis test followed by Dunn's multiple comparisons test were used. (C and D) The paired t-test was used. P $>0.05$ compared to the control.

apoptotic and necrotic cells, as well as late apoptotic/necrotic (on the samples, you have the percentage of each population). We found no statistically significant differences for both cell types and experimental groups (Fig. 5E and F). Therefore, no cytotoxicity was found.

In summary, in this study, we observed that M1 and M8 exerted direct effects on melanoma cells in vitro, when isolated and co-cultured with fibroblasts, in a non-cytotoxic manner. Through different mechanisms, both HDNCs modulated key molecules (ROS, PDGF-B, surface adhesion molecules, and MMP-2) for the melanoma cell metastatic phenotype, leading to a reduction in the capacity of the cells to generate new colonies and invade other tissues (Fig. 6).

\section{Discussion}

The fact that metastatic melanoma is highly refractory to existing therapies has driven several research groups to develop and test potential anti-melanoma products. The majority of anticancer chemotherapeutics used clinically are cytotoxic, which causes severe side-effects for patients with limited effective results against metastatic melanoma. Even though novel leading therapies present better results against this type of cancer, they are closely dependent on the tumor's individual genetic signature and are prohibitively expensive. Therefore, the use of HDNCs may be a cost-effective method for the treatment of melanoma, as lung colonization $(35,36)$ and solid tumor growth (35) have been shown to be impaired in metastatic melanoma-bearing mice treated with M1 and M8. In the present study, we assessed whether these HDNCs can directly act on the malignant parameters of melanoma cells, alone or in an artificial tumor microenvironment (co-cultured with fibroblasts), leading to the attenuation of cell metastasis-related features.

The cell invasive ability is directly related to metastatic competence (38). Cancer cells often exhibit an altered expression of cell-cell and cell-ECM adhesion molecules, such as $\beta 1$-integrins (56), N-cadherin (57) and CD44 (58), leading to changes in migration patterns and promoting the invasion 


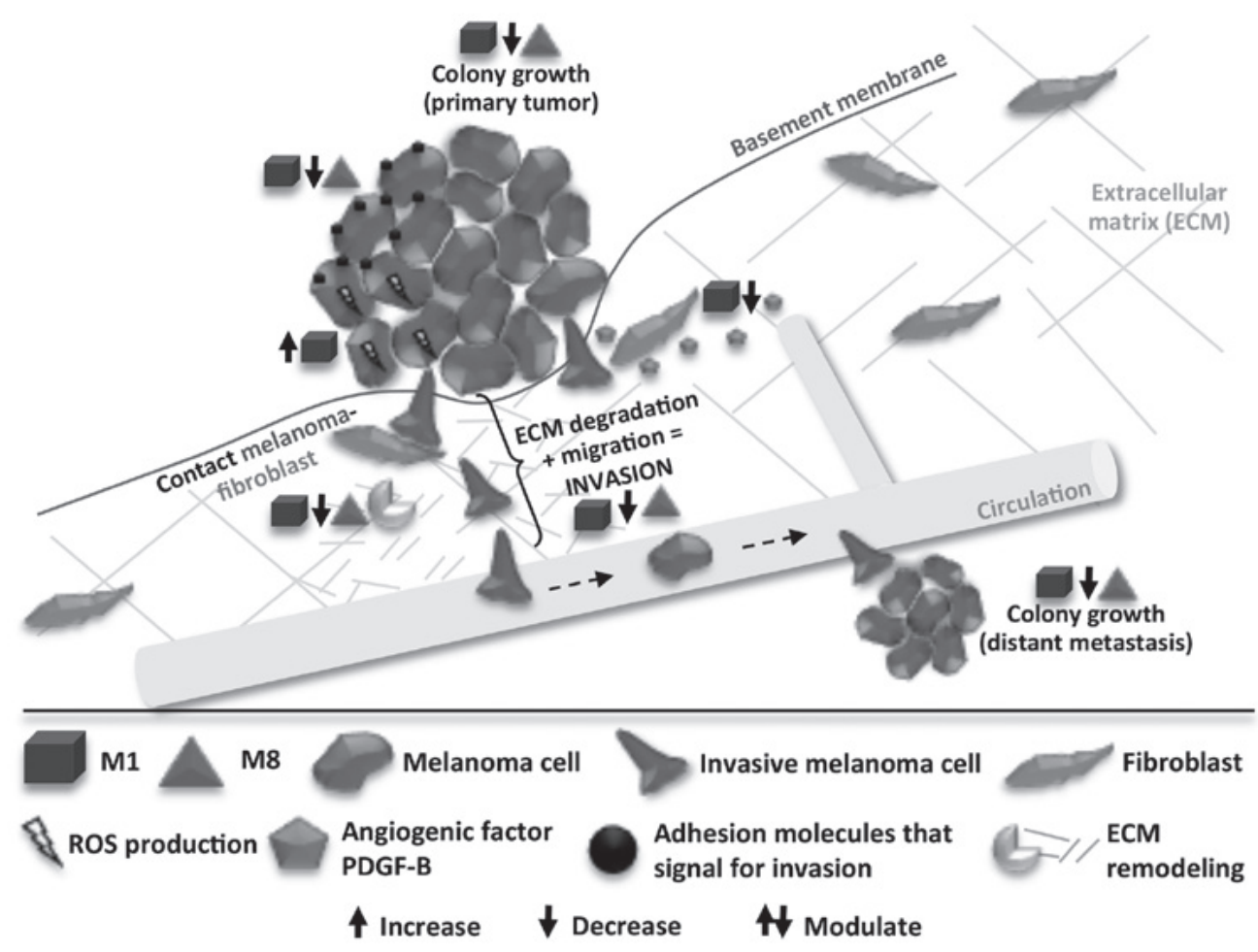

Figure 6. Summary of functional and molecular reprograming of B16-F10 melanoma cells by M1 and M8. Highly diluted natural complexes (HDNCs) affect the metastatic features of melanoma cells in vitro. We identified molecules modulated by HDNCs that directly affect the B16-F10 melanoma cell metastatic phenotype in vitro, alone or in an artificial tumor microenvironment. Melanoma progression features, such as adhesion molecules, cell migratory, invasive and clonogenic capacities, as well as matrix metalloproteinase (MMP)-2 activity were reduced by HDNCs, with no cell damage.

of adjacent tissues (38). In this study, we found that HDNC treatment decreased the migratory and invasive capacities of the melanoma cells (Fig. 1) by the differential modulation of related molecules (Figs. 2 and 3). Although statistically limited, the reduction of the cell invasive capacity following HDNC treatment was very expressive. The results corroborated the reduction in migratory capacity revealed by two different approaches. By comparing the results from the migration and invasion assays, it is possible to note that approximately half of the reduction on invasive capacity promoted by M1 was due to migratory attenuation. For M8, such a contribution accounted for approximately $1 / 3$ of the effect. Although controversial, ROS are also implicated in cell migration (59). M1 treatment, but not M8, enhanced the intracellular ROS levels. On the other hand, M8 reduced CD44 expression, the main receptor for HA that triggers intracellular signal transductions, stimulating migration and invasion processes of melanoma cells (60). Both HDNCs reduced B16-F10 surface $\beta 1$-integrin and $\mathrm{N}$-cadherin, key adhesion molecules that can increase cell migratory capacity.

In addition, cancer cell-ECM interaction, degradation and remodeling (61) are critical steps to invasion (61). In this study, we detected that M1 and M8 differentially modulated ECM-related molecules. Tumor cells often produce MMPs, but upon stimulation, stromal cells are also able to do so (62), and thus the co-culture model is more appropriate for detecting MMP activity. MMP-2 activity was decreased by both HDNCs in the artificial tumor microenvironment, but not when the B16-F10 cells were cultured alone. MMP-2 is the main gelatinolytic enzyme in melanoma, mainly produced at the tumor edges, its invasive front (63). Therefore, the notable finding of ECM degradation reduction by HDNCs may contribute to the impairment of the capacity of tumor cells to escape and spread, thus reducing metastasis.

ECM components and their modulators were also investigated. Hyaluronidase-induced HA fragments can trigger MMP-2 production via TLR4 signaling, stimulating tumor progression (64). In this study, neither HA synthesis nor hyaluronidase-1 expression levels were altered in melanoma cells alone or in the co-culture model. However, HSPG2, an important basement membrane constituent, was upregulated by melanoma cells following M1 treatment. By contrast, the expression of heparanase - the enzyme responsible for heparan sulfate (HS) chain degradation, was downregulated. However, M8 caused no changes in HSPG2 or heparanase expression, but instead upregulated sulfatase- $2 \mathrm{mRNA}$ expression. These results are quite noteworthy as proteoglycan HS chain cleavage by heparanase releases growth factors trapped in the ECM, enhancing its bioavailability (65). In addition, heparanase inhibition on B16 cells was shown to be responsible for the inhibition of invasion in the reconstituted basement membrane (66). Moreover, sulfatases remove 6-O sulfates from $\mathrm{HS}$ chains, which are important for binding to growth factors and their receptors, sustaining its signaling (65). Thus, these results suggest that M1 and M8 interfere via distinct mechanisms with the enzymatic processing of HS chains from proteoglycans, but at the same time can reduce the activity of pro-tumor growth factors.

Growth factors are commonly released in large amounts in the melanoma microenvironment due to cancer cell-fibroblast communications. Along with cytokines, they can stimulate angiogenesis, recruit stromal cells, and promote inflammation and the invasive capacity (67). Melanoma-produced PDGFs $\mathrm{A}$ and $\mathrm{C}$ are the main signaling molecules involved in HA 
synthesis stimulation by CAFs (68). PDGFs A and C expression levels were not affected by HDNCs, which is likely the reason for unaffected HA synthesis. Notably, M1 downregulated PDGF-B expression, a stimulatory signal for connective tissue production around melanoma tumors (69) and for pericyte recruitment (70), which contributes to the formation of new blood vessels. Other important molecules for melanoma migration, invasion and the tumor microenvironment [such as $\mathrm{p}$-AKT, $\beta$-catenin, melanocyte inducing transcription factor (MTIF), melanin, $\alpha$-smooth muscle actin ( $\alpha$-SMA), transforming growth factor (TGF) $\beta 1$ and vascular endothelial growth factor (VEGF)] were addressed, but no changes were found (data not shown).

The extraordinary capacity of cancer cells to overcome growth arrest in growth-limiting conditions allows them to proliferate in new environments (38). In this study, no effects on cell proliferation or cytotoxicity were observed in the anchorage-dependent growth model (2D), although the anchorage-independent growth of pre-treated melanoma cells was decreased (Fig. 4). M8 reduced the number of melanoma-derived colonies, while M1 restrained colony size. The lack of clonogenic capacity by cancer cells is a determinant of reproductive death (71), as it represents the final result of the metastatic process.

Despite scientific evidence of the effectiveness high dilutions for cancer treatment, as well as for other diseases, we often face prejudiced claims that there is no active molecule in such solutions. Fortunately, science regarding the use of homeopathy has evolved. It is currently known that molecules can be kept at the air-liquid interface in between dilutions and be carried to the next ones. In addition, the dilution process involving vigorous shaking may release silicon and silica from the glass vial where it is being produced, which can maintain information from original material under the form of nanoparticles. Therefore, we can now understand high dilutions as a nanomedicine system $(72,73)$. Initial studies on cancer were clinical trials in which the objective was to treat pain or the side-effects caused by chemotherapy (74-77). Recently, a number of other studies have been carried out, with an aim to identify the direct effects of these medicines on cancer cells in vitro. Notably, the majority of the existing literature investigated different highly diluted compounds searching for cytotoxic effects $(19,21,28,78-83)$ or alterations in cell death-related gene expression $(20,84,85)$. In addition, in vitro studies have primarily investigated medications made of single substances. Therefore, we strongly believe that our findings are valuable, not only as they may help to increase the survival of patients with metastasis, but may also lead to important advancements in the field of high dilutions research. Using standard in vitro assays, we were able to elucidate the molecular and functional alterations caused by M1 and M8 directly on isolated cancer cells, and under the tumor microenvironment simulation. The main results are summarized in Fig. 6. The data obtained herein are strongly connected, as we were able to see that the sum of discrete changes on many molecules expression related to cell communication, adhesion, migration, and invasion led to the final effect of reducing melanoma cells invasive and clonogenic capacities in vitro. Likewise, these cell function changes are in strong agreement with previous in vivo results showing M1 and M8 as potent agents against tumor growth and metastasis. However, future studies are warranted in order to validate M1 and M8 as anti-melanoma candidates. Strategies to block specific molecule function should provide more detailed information regarding the contribution of each molecule whose expression has been altered herein for the final effect of M1 or M8. In addition, approaches to determine the active agents must be explored.

In conclusion, previous in vivo studies using murine melanoma models have demonstrated the success of HDNCs in preventing solid tumors to grow and lung nodules to develop as fast as in non-treated animals $(35,36)$. In this study, we were able to elucidate the in vitro cellular mechanisms likely responsible for these in vivo effects. These are important findings as those HDNCs are non-cytotoxic and yet still present prominent effects on reducing main malignancy parameters (migratory, invasive, and clonogenic capacities) of cancer cells in vitro. Unraveling the mechanisms behind such low cost and non-cytotoxic HDNCs could support future studies regarding their possible therapeutic use as one integrative and complementary therapy for patients with metastatic melanoma.

\section{Acknowledgements}

The authors would like to thank Homeoterápica manipulation Pharmacy for preparing and kindly providing the HDNCs, as well as LabCet (ICC/Fiocruz) for purchasing the Balb/3T3 cells from ATCC and kindly providing them so that we could perform the experiments described herein. The authors would also like to thank Dr Silvio M. Zanata [Universidade Federal do Paraná (UFPR)] for providing fibronectin for the Transwell migration assay, and CTAF-UFPR for the acquisition of the migration and invasion assay images. The authors are also grateful to the UFPR Academic Publishing Advisory Center [Centro de Assessoria de Publicação Acadêmica (CAPA)] for assistance with English language editing.

\section{Funding}

This study was financed in part by the Coordenação de Aperfeiçoamento de Pessoal de Nível Superior - Brasil (CAPES) Finance Code 001.

\section{Availability of data and materials}

The datasets used and/or analyzed during the current study are available from the corresponding author on reasonable request.

\section{Authors' contributions}

JPG and FBP planned and conducted the experiments, analyzed and interpreted the obtained data. JPG wrote the manuscript. MLFDS and VSCG helped on the execution of most experiments. GRR and AM under the supervision of HBN planned and conducted HA measurements. TJ under the supervision of SMBW planned, conducted, and analyzed RT-qPCR assays and results. EST and CCDO supervised all steps of assays planning and results interpretation, and also revised the manuscript. All authors have read and approved the final manuscript 


\section{Ethics approval and consent to participate}

Not applicable.

\section{Patient consent for publication}

Not applicable.

\section{Competing interests}

The authors declare that they have no competing interests.

\section{References}

1. Torre LA, Bray F, Siegel RL, Ferlay J, Lortet-Tieulent J and Jemal A: Global cancer statistics, 2012. CA Cancer J Clin 65 $87-108,2015$.

2. Lomas A, Leonardi-Bee J and Bath-Hextall F: A systematic review of worldwide incidence of nonmelanoma skin cancer. $\mathrm{Br}$ J Dermatol 166: 1069-1080, 2012.

3. Guy GP Jr, Thomas CC, Thompson T, Watson M, Massetti GM and Richardson LC; Centers for Disease Control and Prevention (CDC): Vital signs: Melanoma incidence and mortality trends and projections - United States, 1982-2030. MMWR Morb Mortal Wkly Rep 64: 591-596, 2015

4. American Cancer Society: Survival Rates for Melanoma Skin Cancer, by Stage. American Cancer Society, Atlanta, GA 2017. https://www.cancer.org/cancer/melanoma-skin-cancer/ detection-diagnosis-staging/survival-rates-for-melanoma-skincancer-by-stage.html. Accessed February 1, 2019.

5. Maverakis E, Cornelius LA, Bowen GM, Phan T, Patel FB, Fitzmaurice S, He Y, Burrall B, Duong C, Kloxin AM, et al Metastatic melanoma - A review of current and future treatment options. Acta Derm Venereol 95: 516-524, 2015.

6. American Cancer Society: Skin Cancer. American Cancer Society, Inc., Atlanta, GA, 2016. http://www.cancer.org/cancer/cancercauses/ sunanduvexposure/skin-cancer-facts. Accessed May 10, 2018

7. Ryu SH, Heo SH, Park EY, Choi KC, Ryu JW, Lee SH and Lee SW: Selumetinib inhibits melanoma metastasis to mouse liver via suppression of EMT-targeted genes. Anticancer Res 37: 607-614, 2017

8. Sadhu SS, Wang S, Averineni RK, Seefeldt T, Yang Y and Guan X: In-vitro and in-vivo inhibition of melanoma growth and metastasis by the drug combination of celecoxib and dacarbazine. Melanoma Res 26: 572-579, 2016.

9. Ibrahim N and Haluska FG: Molecular pathogenesis of cutaneous melanocytic neoplasms. Annu Rev Pathol 4: 551-579, 2009.

10. Luke JJ, Flaherty KT, Ribas A and Long GV: Targeted agents and immunotherapies: Optimizing outcomes in melanoma. Nat Rev Clin Oncol 14: 463-482, 2017.

11. Luo $\mathrm{C}$ and Shen J: Research progress in advanced melanoma. Cancer Lett 397: 120-126, 2017.

12. Eggermont AM and Robert C: New drugs in melanoma: It's a whole new world. Eur J Cancer 47: 2150-2157, 2011.

13. Hanahan D and Weinberg RA: The hallmarks of cancer. Cell 100: $57-70,2000$

14. Melis C, Rogiers A, Bechter O and van den Oord JJ: Molecular genetic and immunotherapeutic targets in metastatic melanoma. Virchows Arch 471: 281-293, 2017.

15. Workman P, Draetta GF, Schellens JH and Bernards R: How much longer will we put up with $\$ 100,000$ cancer drugs? Cell 168: 579-583, 2017

16. World Health Organization: WHO Traditional Medicine Strategy: 2014-2023. WHO Press, Geneva, p76, 2013.

17. Ghosh S, Sikdar S, Mukherjee A and Khuda-Bukhsh AR: Evaluation of chemopreventive potentials of ethanolic extract of Ruta graveolens against A375 skin melanoma cells in vitro and induced skin cancer in mice in vivo. J Integr Med 13: 34-44, 2015.

18. Mondal J, Samadder A and Khuda-Bukhsh AR: Psorinum 6x triggers apoptosis signals in human lung cancer cells. J Integr Med 14: 143-153, 2016.

19. Sikdar S, Kumar Saha S and Rahman Khuda-Bukhsh A: Relative apoptosis-inducing potential of homeopa-thic Condurango $6 \mathrm{C}$ and 30C in H460 lung cancer cells in vitro: -Apoptosis-induction by homeopathic Condurango in H460 cells. J Pharmacopuncture 17: $59-69,2014$.
20. Saha SK, Roy S and Khuda-Bukhsh AR: Ultra-highly diluted plant extracts of Hydrastis canadensis and Marsdenia condurango induce epigenetic modifications and alter gene expression profiles in HeLa cells in vitro. J Integr Med 13: 400-411, 2015.

21. Arora S and Tandon S: DNA fragmentation and cell cycle arrest: A hallmark of apoptosis induced by Ruta graveolens in human colon cancer cells. Homeopathy 104: 36-47, 2015.

22. Khuda-Bukhsh AR: Modulation of TERT and Top II activities by the homeopathic nosode, Hep C 30 in demonstrating its anticancer potential against Hep G2 liver cancer cells: A commentary on one of our Published Research Anisur. BAOJ Med Nurs 4: 2, 2018.

23. Ministério da Saúde (ed): Política Nacional de Práticas Integrativas e Complementares no SUS. 2nd edition. Biblioteca Virtual em Saúde do Ministério da Saúde, Brasil, p98, 2015 (In Portuguese).

24. de Oliveira CC, de Oliveira SM, Godoy LM, Gabardo J and Buchi DF: Canova, a Brazilian medical formulation, alters oxidative metabolism of mice macrophages. J Infect 52: 420-432, 2006

25. Abud AP, Cesar B, Cavazzani LF, de Oliveira CC, Gabardo J and Buchi DF: Activation of bone marrow cells treated with Canova in vitro. Cell Biol Int 30: 808-816, 2006.

26. Lopes L, Godoy LM, de Oliveira CC, Gabardo J, Schadeck RJ and de Freitas Buchi D: Phagocytosis, endosomal/lysosomal system and other cellularaspects of macrophage activation by Canova medication. Micron 37: 277-287, 2006.

27. Cesar B, Abud AP, de Oliveira CC, Cardoso F, Gremski W, Gabardo J and Buchi DF: Activation of mononuclear bone marrow cells treated in vitro with a complex homeopathic medication. Micron 39: 461-470, 2008.

28. Guimarães FS, Abud AP, Oliveira SM, Oliveira CC, César B, Andrade LF, Donatti L, Gabardo J, Trindade ES and Buchi DF: Stimulation of lymphocyte anti-melanoma activity by co-cultured macrophages activated by complex homeopathic medication. BMC Cancer 9: 293, 2009.

29. de Oliveira CC, Abud AP, de Oliveira SM, Guimarães FS, de Andrade LF, Di Bernardi RP, Coletto EL, Kuczera D, Da Lozzo EJ, Gonçalves JP, et al: Developments on drug discovery and on new therapeutics: Highly diluted tinctures act as biological response modifiers. BMC Complement Altern Med 11: 101, 2011.

30. de Oliveira SM, de Oliveira CC, Abud AP, Guimarães FS, Di Bernardi RP, Coletto EL and Buchi DF: Mercurius solubilis: Actions on macrophages. Homeopathy 100: 228-236, 2011.

31. Gonçalves JP, Dos Santos MLF, Rossi GR, Costa Gagosian VS and de Oliveira CC: Differential effects of Zincum metallicum on cell models. Homeopathy 106: 171-180, 2017.

32. Sato DY, Wal R, de Oliveira CC, Cattaneo RII, Malvezzi M, Gabardo J and Buchi DF: Histopathological and immunophenotyping studies on normal and sarcoma 180-bearing mice treated with a complex homeopathic medication. Homeopathy 94: 26-32, 2005.

33. de Oliveira CC, de Oliveira SM, Goes VM, Probst CM, Krieger MA and Buchi DF: Gene expression profiling of macrophages following mice treatment with an immunomodulator medication. J Cell Biochem 104: 1364-1377, 2008

34. Cesar B, Abud AP, de Oliveira CC, Cardoso F, Bernardi RP, Guimarães FS, Gabardo J and de Freitas Buchi D: Treatment with at homeopathic complex medication modulates mononuclear bone marrow cell differentiation. Evid Based Complement Alternat Med 2011: 212459, 2011

35. Ferrari de Andrade L, Mozeleski B,Leck AR, Rossi G, da Costa CR, de Souza Fonseca Guimarães F, Zotz R, Fialho do Nascimento K, Camargo de Oliveira C, de Freitas Buchi D, et al: Inhalation therapy with $\mathrm{M} 1$ inhibits experimental melanoma development and metastases in mice. Homeopathy 105: 109-118, 2016.

36. Guimarães FS, Andrade LF, Martins ST, Abud AP, Sene RV, Wanderer C, Tiscornia I, Bollati-Fogolín M, Buchi DF and Trindade ES: In vitro and in vivo anticancer properties of a Calcarea carbonica derivative complex (M8) treatment in a murine melanoma model. BMC Cancer 10: 113, 2010.

37. Lambert AW, Pattabiraman DR and Weinberg RA: Emerging Biological Principles of Metastasis. Cell 168: 670-691, 2017.

38. Hanahan D and Weinberg RA: Hallmarks of cancer: The next generation. Cell 144: 646-674, 2011.

39. Kam Y, Rejniak KA and Anderson AR: Cellular modeling of cancer invasion: Integration of in silico and in vitro approaches. J Cell Physiol 227: 431-438, 2012.

40. Hanahan D and Coussens LM: Accessories to the crime: Functions of cells recruited to the tumor microenvironment. Cancer Cell 21: 309-322, 2012 
41. Balkwill FR, Capasso M and Hagemann T: The tumor microenvironment at a glance. J Cell Sci 125: 5591-5596, 2012.

42. Kalluri R: The biology and function of fibroblasts in cancer. Nat Rev Cancer 16: 582-598, 2016.

43. Bogenrieder T and Herlyn M: Axis of evil: Molecular mechanisms of cancer metastasis. Oncogene 22: 6524-6536, 2003.

44. Lima LF, Rocha RM, Duarte AB, Brito IR, Silva GM, Rodrigues GQ Nunes-Pinheiro DC, Sales AD, Moura AA, Wheeler MB, et al: Unexpected effect of the vehicle (grain ethanol) of homeopathic FSH on the in vitro survival and development of isolated ovine preantral follicles. Microsc Res Tech 80: 406-418, 2017.

45. Chirumbolo $\mathrm{S}$ and Bjørklund G: Homeopathic potencies of Arnica montana L. change gene expression in a Tamm-Horsfall protein-1 cell line in vitro model: The role of ethanol as a possible confounder and statistical bias. J Integr Med 15: 255-264, 2017.

46. Young L, Sung J, Stacey G and Masters JR: Detection of Mycoplasma in cell cultures. Nat Protoc 5: 929-934, 2010.

47. Justus CR, Leffler N, Ruiz-Echevarria M and Yang LV: In vitro cell migration and invasion assays. J Vis Exp 88: e51046, 2014.

48. Eruslanov E and Kusmartsev S: Identification of ROS using oxidized DCFDA and flow-cytometry. Methods Mol Biol 594: 57-72, 2010.

49. Martins JR, Passerotti CC, Maciel RM, Sampaio LO, Dietrich CP and Nader HB: Practical determination of hyaluronan by a new noncompetitive fluorescence-based assay on serum of normal and cirrhotic patients. Anal Biochem 319: 65-72, 2003.

50. Vandesompele J, De Preter K, Pattyn F, Poppe B, Van Roy N, De Paepe A and Speleman F: Accurate normalization of real-time quantitative RT-PCR data by geometric averaging of multiple internal control genes. Genome Biol: Jun 18, 2002 (Epub ahead of print).

51. Toth M and Fridman R: Assessment of gelatinases (MMP-2 and MMP-9 by gelatin zymography. Methods Mol Med 57: 163-174 2001.

52. Bonnekoh B, Wevers A, Jugert F,Merk H and Mahrle G: Colorimetric growth assay for epidermal cell cultures by their crystal violet binding capacity. Arch Dermatol Res 281: 487-490, 1989.

53. Mosmann T: Rapid colorimetric assay for cellular growth and survival: Application to proliferation and cytotoxicity assays. J Immunol Methods 65: 55-63, 1983.

54. Schneider CA, Rasband WS and Eliceiri KW: NIH Image to ImageJ: 25 years of image analysis. Nat Methods 9: 671-675, 2012.

55. Terho P: Flowing Software. Turku Centre for Biotechnology, 2013. http://flowingsoftware.btk.fi/index.php?page=1.

56. Kuphal S, Bauer R and Bosserhoff A-K: Integrin signaling in malignant melanoma. Cancer Metastasis Rev 24: 195-222, 2005

57. Li G, Satyamoorthy K and Herlyn M: N-cadherin-mediated intercellular interactions promote survival and migration of melanoma cells. Cancer Res 61: 3819-3825, 2001.

58. Dietrich A, Tanczos E, Vanscheidt W, Schöpf E and Simon JC: High CD44 surface expression on primary tumours of malignant melanoma correlates with increased metastatic risk and reduced survival. Eur J Cancer 33: 926-930, 1997.

59. Herraiz C, Crosas-Molist E and Sanz-Moreno V: Reactive oxygen species and tumor dissemination: Allies no longer. Mol Cell Oncol 3: e1127313, 2016

60. Sironen RK, Tammi M, Tammi R, Auvinen PK, Anttila M and Kosma VM: Hyaluronan in human malignancies. Exp Cell Res 317: 383-391, 2011.

61. Bonnans C, Chou J and Werb Z: Remodelling the extracellular matrix in development and disease. Nat Rev Mol Cell Biol 15 786-801, 2014.

62. Hofmann UB, Westphal JR, Zendman AJW, Becker JC, Ruiter DJ and van Muijen GN: Expression and activation of matrix metalloproteinase-2 (MMP-2) and its co-localization with membrane-type 1 matrix metalloproteinase (MT1-MMP) correlate with melanoma progression. J Pathol 191: 245-256, 2000.

63. Kurschat P, Wickenhauser C, Groth W, Krieg T and Mauch C: Identification of activated matrix metalloproteinase-2 (MMP-2) as the main gelatinolytic enzyme in malignant melanoma by in situ zymography. J Pathol 197: 179-187, 2002.

64. Voelcker V, Gebhardt C, Averbeck M, Saalbach A, Wolf V, Weih F, Sleeman J, Anderegg U and Simon J: Hyaluronan fragments induce cytokine and metalloprotease upregulation in human melanoma cells in part by signalling via TLR4. Exp Dermatol 17: 100-107, 2008.

65. Sanderson RD, Yang Y, Kelly T, MacLeod V, Dai Y and Theus A Enzymatic remodeling of heparan sulfate proteoglycans within the tumor microenvironment: Growth regulation and the prospect of new cancer therapies. J Cell Biochem 96: 897-905, 2005.
66. Nakajima M, DeChavigny A, Johnson CE, Hamada J, Stein CA and Nicolson GL: Suramin. A potent inhibitor of melanoma heparanase and invasion. J Biol Chem 266: 9661-9666, 1991.

67. Herlyn M and Shih IM: Interactions of melanocytes and melanoma cells with the microenvironment. Pigment Cell Res 7: 81-88, 1994

68. Willenberg A, Saalbach A, Simon JC and Anderegg U Melanoma cells control HA synthesis in peritumoral fibroblasts via PDGF-AA and PDGF-CC: Impact on melanoma cell proliferation. J Invest Dermatol 132: 385-393, 2012.

69. Forsberg K, Valyi-Nagy I, Heldin $\mathrm{CH}$, Herlyn $M$ and Westermark B: Platelet-derived growth factor (PDGF) in oncogenesis: Development of a vascular connective tissue stroma in xenotransplanted human melanoma producing PDGF-BB. Proc Natl Acad Sci USA 90: 393-397, 1993.

70. Abramsson A, Lindblom P and Betsholtz C: Endothelial and nonendothelial sources of PDGF-B regulate pericyte recruitment and influence vascular pattern formation in tumors. J Clin Invest 112: 1142-1151, 2003

71. Kroemer G, Galluzzi L, Vandenabeele P, Abrams J, Alnemri ES, Baehrecke EH, Blagosklonny MV, El-Deiry WS, Golstein P, Green DR, et al: Classification of cell death: recommendations of the Nomenclature Committee on Cell Death 2009. Cell Death Differ 16: 3-11, 2009.

72. Chikramane PS, Kalita D, Suresh AK, Kane SG and Bellare JR: Why extreme dilutions reach non-zero asymptotes: A nanoparticulate hypothesis based on froth flotation. Langmuir 28: 15864-15875, 2012.

73. Upadhyay RP and Nayak C: Homeopathy emerging as nanomedicine. Int J High Dilution Res 10: 299-310, 2011.

74. Thompson EA and Reillly D: The homeopathic approach to symptom control in the cancer patient: A prospective observational study. Palliat Med 16: 227-233, 2002

75. Burton MJ, Couch ME and Rosenfeld RM: Extracts from the Cochrane Library: Homeopathic medicines for adverse effects of cancer treatments. Otolaryngol Head Neck Surg 141: 162-165, 2009.

76. Orellana Alvarellos G, Ruiz de Viñaspre Alvear P and Kaszkin-Bettag M: A series of case reports: Clinical evaluation of a complex homeopathic injection therapy in the management of pain in patients after breast cancer treatment. Altern Ther Health Med 16: 54-59, 2010.

77. Oberbaum M, Yaniv I, Ben-Gal Y, Stein J, Ben-Zvi N Freedman LS and Branski D: A randomized, controlled clinical trial of the homeopathic medication TRAUMEEL $S$ in the treatment of chemotherapy-induced stomatitis in children undergoing stem cell transplantation. Cancer 92: 684-690, 2001.

78. Samadder A, Das S, Das J, Paul A, Boujedaini N and KhudaBukhsh AR: The potentized homeopathic drug, Lycopodium clavatum $(5 \mathrm{C}$ and $15 \mathrm{C})$ has anti-cancer effect on hela cells in vitro. J Acupunct Meridian Stud 6: 180-187, 2013.

79. Preethi K, Ellanghiyil S, Kuttan G and Kuttan R: Induction of apoptosis of tumor cells by some potentiated homeopathic drugs: Implications on mechanism of action. Integr Cancer Ther 11: 172-182, 2012.

80. Arora S, Aggarwal A, Singla P, Jyoti S and Tandon S: Antiproliferative effects of homeopathic medicines on human kidney, colon and breast cancer cells. Homeopathy 102: 274-282, 2013.

81. Benkendorff K, McIver CM and Abbott CA: Bioactivity of the murex homeopathic remedy and of extracts from an australian muricid mollusc against human cancer cells. Evid Based Complement Alternat Med 2011: 879585, 2011

82. Frenkel M, Mishra BM, Sen S, Yang P, Pawlus A, Vence L, Leblanc A, Cohen L, Banerji P and Banerji P: Cytotoxic effects of ultra-diluted remedies on breast cancer cells. Int J Oncol 36: 395-403, 2010

83. MacLaughlin BW, Gutsmuths B, Pretner E, Jonas WB, Ives J, Kulawardane DV and Amri H: Effects of homeopathic preparations on human prostate cancer growth in cellular and animal models. Integr Cancer Ther 5: 362-372, 2006

84. Saha SK, Roy S and Khuda-Bukhsh AR: Evidence in support of gene regulatory hypothesis: Gene expression profiling manifests homeopathy effect as more than placebo. Int J Hight Dilution Res 12: 162-167, 2013.

85. Thangapazham RL, Gaddipati JP, Rajeshkumar NV, Sharma A, Singh AK, Ives JA, Maheshwari RK and Jonas WB: Homeopathic medicines do not alter growth and gene expression in prostate and breast cancer cells in vitro. Integr Cancer Ther 5: 356-361, 2006. 